\title{
Integration of Local Wisdom Mangrove Ecotourism in Class IV Learning in Elementary School
}

\author{
Syahrial1', Asrial2, Maison', Dwi Agus Kurniawan ${ }^{4}$, Muhammad Toto Nugroho 5 \\ 1,2,3,4,5 Universitas Jambi, Indonesia
}

@dwiagus.k@unja.ac.id

\begin{tabular}{|c|c|}
\hline \multirow[b]{2}{*}{$\begin{array}{l}\text { ARTICLE INFO } \\
\text { Article history: } \\
\text { Received } \\
\text { October 20, } 2020 \\
\text { Revised } \\
\text { February 08, } 2021 \\
\text { Accepted } \\
\text { July 18., } 2021\end{array}$} & ABSTRACT \\
\hline & $\begin{array}{l}\text { This article aims to integrate local wisdom of Mangrove Ecotourism in } \\
\text { the learning process in elementary schools to meet the demands of the } \\
2013 \text { curriculum based on local wisdom. This type of research is } \\
\text { descriptive qualitative research using ethnography. The research sample } \\
\text { consisted of } 7 \text { informants, with two community leaders, two people from } \\
\text { the Youth and Sports Tourism Office and three classroom teachers. This } \\
\text { research, using instrument through observation, interviews, and } \\
\text { documentation. The results of the study found that local wisdom of } \\
\text { Mangrove Ecotourism can be applied in the learning process in grade IV } \\
\text { elementary schools and can provide excellent benefits in the } \\
\text { development of the developmental aspects of students not only in } \\
\text { cognitive aspects but in affective and psychomotor aspects of students. }\end{array}$ \\
\hline & Keywords: Local Wisdom, Ecotourism Mangrove, Learning Activity \\
\hline How to cite & $\begin{array}{l}\text { Syahrial, S., et al., (2021). Integration of Local Wisdom Mangrove Ecotourism in } \\
\text { Class IV Learning in Elementary School. Jurnal Iqra' : Kajian Ilmu Pendidikan, } \\
\text { 6(2). 61-70. } \\
\text { https://doi.org/10.25217/ji.v6i1.1142 }\end{array}$ \\
\hline Journal Homepage & $\begin{array}{l}\text { http://journal.iaimnumetrolampung.ac.id/index.php/ji/ } \\
\text { rticle under the CC BY SA license } \\
\text { https://creativecommons.org/licenses/by-sa/4.0/ }\end{array}$ \\
\hline
\end{tabular}

\section{INTRODUCTION}

The 2013 curriculum is structured to improve attitudes and knowledge in a balanced manner (Machali, 2014). Not only curriculum improvement, but also learning in schools also needs to be improved, this is in line with (Guvercin \& Verbovskiy, 2014) which states "Traditional methods does not give meaning because it does not take into account the psychological attitudes and students". At school level efforts need to be done to make sure that learning environment as well as school management are concurrently contributing to student learning (Winataputra \& Riza, 2013). In the current era of 4.0, local wisdom-based learning can be seen as learning that is more innovative and very useful. Albantani \& Madkur (2018) explain "The integration of local wisdom is very essential and it could be executed by including the local wisdom, values into the materials", The use of local wisdom-based learning model is proven to improve student's conservationist character (Kusnianti, et al., 2017).

In implementing the 2013 curriculum, which emphasizes developing attitudes in students, teaching materials are needed that can develop students' self-attitudes. Teaching materials are not only to equip students with knowledge, but far more beyond (Anggarini \& Kusniarti, 2015). Teaching materials themselves have an important role in learning to achieve planned goals. By integrating local wisdom, can train students communication skills, collect information and conduct investigations in 
the community (Hairida, 2017) learning based on local wisdom can improve the knowledge and social attitudes of students (Uge et al., 2019) and local wisdom-based learning is very essential that students acquire intelligence in thinking (Ningrum \& Sungkawa, 2018). Learning based on local wisdom, can actually help learners improve critical thinking ability even in the form of small scal (Oktavia, et.all, 2018) in line with local wisdom-based learning can improve thinking skills (Putri \& Aznam, 2019). Local wisdom in each region itself has a lot of educational value that can be taught to students, especially at the elementary school level through teaching materials.

Tanjung, et al (2018) explain Teaching material is a set of teaching material (information, material, and text) arranged systematically and used in learning. Saglam (2011) states "Teaching materials provide a great deal of convenience in teacher's ability to convey a message to students in an accurate, proper, clear and understandable manner". Teaching materials used in the learning process should be oriented to the environment around the students, this is confirmed by Permendikbud Number $81 \mathrm{~A}$ in appendix I Regarding educational development, each region requires education in accordance with regional characteristics. Based on this regulation, the teaching materials to be used should integrate the local wisdom of each region, but in fact there are still some teachers who have not implemented this. The teacher learning process only uses teaching materials such as teacher's books and student books, where the content of local wisdom material is different from the local wisdom of each region, this statement is in accordance with Abadi, et al (2015) suggested that the lack of teaching materials based scientific approach we have challenges in the curriculum in 2013 itself, which students use technology/electronic media as learning support.

Suastra, et al (2017) asserted that Local wisdom is substantially a norm that is binding in a community whose truth is believed by the community and whose existence is used as the reference in daily activities and behaviors" while Yamin (2017) assumed the knowledge being discovered or acquired by local people through the accumulation of experience in trials and it is integrated by understanding the surrounding nature and culture", and local wisdom is a process of realization in increasing the valuable local potential so that it becomes a product, a service, or other valuable works, which has a unique and comparative advantage (Subali, et al. 2015) Anwari \& Sulistyowati (2016) explained local wisdom as a product of local knowledge is extremely important in providing a local context in science development. Thus, local wisdom is both a tradition and the potential for natural resources contained in an area to be utilized in various fields of community life.

Apart from being a means of filtering the impact of the development of the modern era, Shaleha \& Purbani (2019) explain "The impact of globalization makes people lose their identity and forget their own culture because of the changes of society". For this reason, the function of local wisdom as stated by Syahputra (2019), namely "In the current era of globalization and modernization, local wisdom also plays a role as filtered values, namely choosing which values are positive and worthy to be taken and which values are not. worth taking ". One of the functions of local wisdom is that it can improve the quality of existing education, according to Sibarani (2018) arguing "The local wisdom which can be used to increase the welfare includes hard work, discipline, education", Santosa (2019) argued "Teaching materials based on local wisdom will be more useful if it does not only contain local cultural values but is also able to improve survival skills needed in the 21st century". Local wisdom can improve the quality of education because by utilizing the environment around students can make learning that students perceive more meaningful, in line with Vallori (2014) 
argues "Meaningful learning, which implies longer retention than memorizing, occurs when humans relate new concepts to the pre-existing familiar concept ". Therefore local wisdom must be integrated into learning.

Not only does it make learning more meaningful, but the role of local wisdom in education is also wider. Wagiran (2012) fattens "Local wisdom is the capital for the formation of noble character", while education that collaborates the role of local wisdom in improving the process and improving the quality of education (Kusuma, 2018) Utari, et al (2016) explains "Learning Thematic based on local knowledge is expected to be used as provisions and prepare students to become human beings who have better quality and competence. So by integrating local wisdom that exists in an area, the quality of education will increase because the noble character of students will be formed, and existing learning is much more meaningful. One of the local wisdoms that can be integrated into learning in the 2013 curriculum is Mangrove Ecotourism in Pangkal Babu, West Tanjung Jabung Regency. Mangrove Ecotourism is a mangrove forest ecosystem on the beach, which consists of various types of mangrove plants and animals. With the abundant natural resources in Mangrove Ecotourism, making Mangrove Ecotourism feels appropriate for learning in Elementary Schools. Therefore, this study aims to integrate the value of local wisdom in the form of mangroves into learning for grade Iin elementary school. Because in current learning, it is required to integrate learning with the surrounding environment (Su, 2012; Alsubaie, 2016). Therefore the novelty of this research is the integration of the local wisdom values of mangrove plants into learning.

\section{METHOD}

This study uses a qualitative approach with the method used is ethnography. Qualitative research is carried out in natural conditions and the data collected and the analysis is more qualitative (Sugiono, 2017: 8). The qualitative approach in this research is used to explore local wisdom of Mangrove Ecotourism which will be integrated into learning in grade IV elementary schools.

In taking the sample, it is determined in advance who can be taken as the sample based on the research objectives (Bachri, 2010). Samples are usually small and selected according to the purpose (objectives) of the study. The researcher must explain why certain people are being sampled, as well as why certain backgrounds were observed. Creswell, (2014), suggests "a qualitative method that has several characteristics, namely control of the natural environment, inductive, flexible, direct experience, depth of process, capturing meaning, totality, active participation of participants and interpretation". The subjects in this study were seven informants with details, namely two community leaders, two people from the Youth and Sports Tourism Office and three classroom teachers. To provide accurate information about mangrove ecotourism and teaching materials based on local wisdom in elementary schools. In this study, the instruments used included observation, open interviews, and documentation studies.

In analyzing the data collected, data reduction. Data analysis technique is a process of searching, compiling, classifying all the data obtained by researchers from observations. Researchers used the data analysis technique of Miles and Hubberman (1994) with the following steps: Data Reduction, Reducing data means summarizing, sorting out main things, focusing on things that are important. Presentation of data, presenting the data most used in qualitative research is narrative text. Withdrawal. Collections in qualitative research are new findings that have never existed before. 


\section{RESULT AND DISCUSSION}

\section{Results of Interview with Community Leaders}

Interviews with community leaders were conducted with the head of the local village as well as someone active in maintaining and preserving Mangrove Ecotourism. He stated that Mangrove Ecotourism has been around for a long time, but it was only inaugurated at the end of 2019. This ecotourism has various natural resources, with the presence of various types of mangrove plants, types of animals typical of coastal areas, and stated that Mangrove Ecotourism very potential if it is used as a learning tool for students, especially students at the elementary school level. He also explained that this ecotourism site was once used as a research site for university students. Apart from being a learning material for both students and students, Mangrove Ecotourism is one of the economic drivers of the surrounding community. It is not only used for tourism areas but also used for aquaculture areas by making ponds as a place for aquaculture, not only that local community groups also make use of it. mangrove ecosystem as raw material for handicrafts. So the results of interviews with community leaders show that Mangrove Ecotourism has educational values, namely the value of love for the environment, where students can love the environment in which they live, and knowledge of the types of animals and plants along with the functions and benefits of mangrove ecotourism.

\section{Results of Interview with the Youth and Sports Tourism Office Interview with the Tourism}

Office of West Tanjung Jabung Regency represented by the Head of Tourism, he explained that Mangrove Ecotourism is intensively in the process of repair to support various areas of life in the surrounding community because the surrounding community is very dependent on sustainability from the mangrove ecosystem as a source of income either by selling in tourist areas or making handicrafts with raw materials from the ecosystem. Disparpora's efforts to conserve it by planting mangrove trees and issuing regulations on mangrove protection and conservation. According to information obtained from the Head of the Tourism Division of the Tourism Office of West Tanjung Jabung Regency, Mangrove Ecotourism can very well be integrated into learning because of the enormous potential contained in Ecotourism. There is hope that Disparpora conveyed to researchers, namely that they can incorporate Mangrove Ecotourism into the world of education today. The results of interviews with Disparpora figures, namely Mangrove Ecotourism, are very suitable to be included in learning in elementary schools because they have a character value of caring for the environment, the value of education because they recognize the importance of a mangrove ecosystem for people's lives.

\section{Results of Interview with Primary School Teachers.}

Activities with grade IV elementary school teachers revealed that researchers got some information about the learning process and the availability of teaching materials that are integrated with local wisdom. According to him, so far teaching and learning activities that have been carried out can be said that there are still few learning materials that are associated with local wisdom, this is because teaching materials that are directly integrated with local potential or local wisdom are not available. Also, he explained that the learning process that is integrated with local wisdom is only limited to the subject of Cultural Arts, and the integration process only introduces local wisdom in the form of folk songs and regional dances. He gave a message to 
researchers so that in the future they can make teaching materials that are integrated directly with local wisdom because by integrating existing local wisdom it can make learning better, with children being more enthusiastic in learning, besides that students can reap values contained in local wisdom, both in terms of knowledge, character, and skills in managing local wisdom. So it can be concluded that currently there is still a lack of teaching materials that are integrated with the local wisdom of their respective regions, even though using teaching materials that are integrated with local wisdom can provide excellent benefits for students in teaching and learning activities in elementary schools

\section{Document Study}

The study carried out in this research is by analyzing the 2013 curriculum syllabus, Core Competencies, Basic Competencies, and learning at the fourth grade level of Elementary School, which aims to determine the Core Competencies, Basic Competencies, and learning which will be integrated with local wisdom of ecotourism Mangroves Pangkal Babu. The results of the document analysis are as follows.

Table 1. Basic Competency Class IV Theme 3 Subtheme 1 Learning 1

$\begin{array}{lcc}\begin{array}{l}\text { Competency Basic } \\ \text { Science }\end{array} & \begin{array}{c}\text { Competency Basic } \\ \text { Indonesian }\end{array} & \text { Basic Competency IPS }\end{array}$

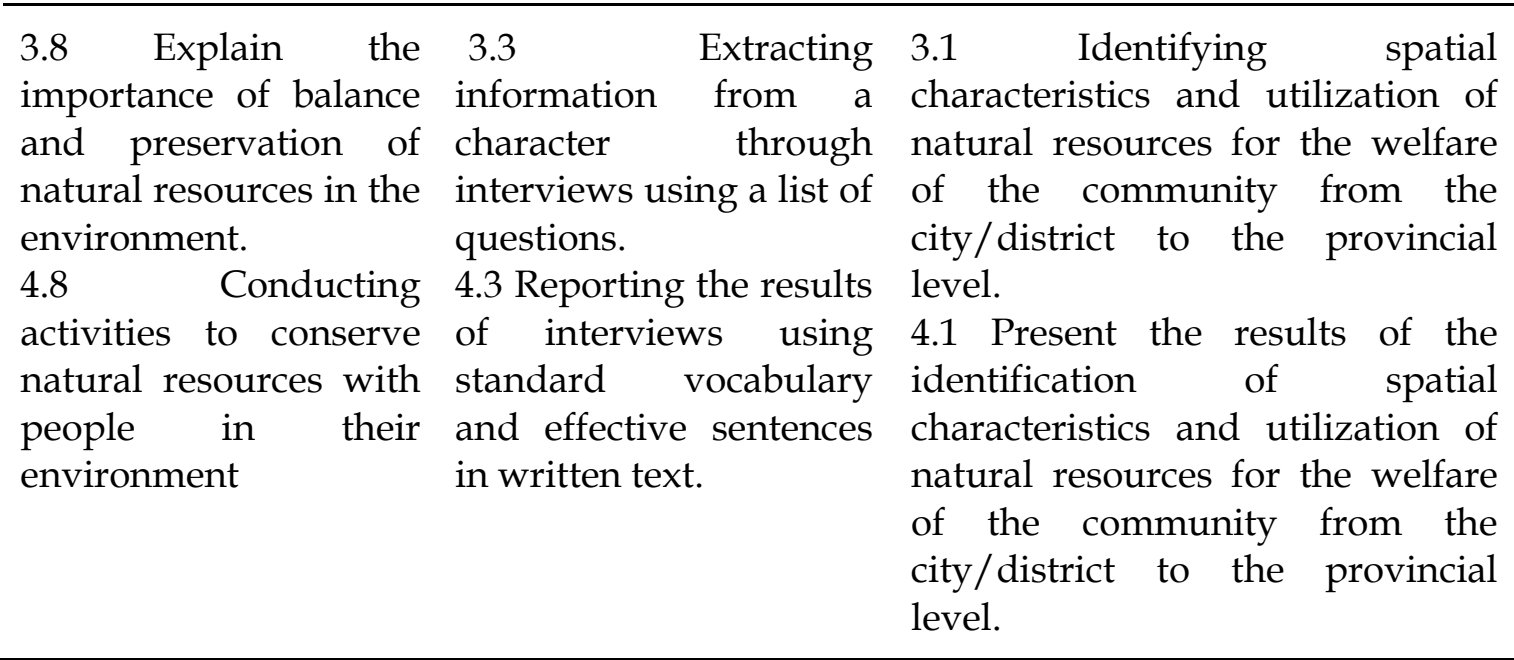

After conducting observations, interviews, and document studies, mangrove ecotourism can be integrated into the learning process in class IV under Theme 3 Caring for the Environment Sub-theme 1 Animals and Plants Around My House. Then the integration of local wisdom of Mangrove Ecotourism with Class IV Basic Competence (KD) can be applied in several ways, among others. In science content, it can be done by providing reading materials and learning videos that contain the conditions around Mangrove Ecotourism and students can identify problems with the environmental balance of Mangrove Ecotourism. The Indonesian language content can be integrated by presenting reading texts about Mangrove Ecotourism that are not too detailed, this is done so that students with teacher guidance can make a list of interview questions which will later be used when conducting interviews on-field learning activities to explore more information about local wisdom. The contents of the IPS material are integrated by presenting video footage of the life of the community 
around Mangrove Ecotourism, with this video students can discuss with their friends the characteristics and importance of Mangrove Ecotourism for the lives of the surrounding community.

Learning materials that have been integrated with mangrove ecotourism can be implemented with various learning methods in the current 2013 curriculum, there are many benefits for students when carrying out learning activities integrated with local wisdom, one of which is mangrove ecotourism, according to Majid, (2016) the mangrove ecosystem has various potential benefits both directly and indirectly. Based on the results of interviews from the three informants, the inclusion of mangrove ecotourism in the learning process can improve the character of environmental care for students, this is because mangrove ecotourism has a very important role in people's lives, not only as a barrier. seawater erosion but also as a source of an economic driving force for the surrounding community, it is very important to be preserved. This is by the research of Ratnasari et al., (2017), Saputri (2019), and Sulistyowati et al., (2020), which results in a learning process that is integrated with the local potential of mangrove forests to improve the character of environmental care.

By integrating local wisdom such as Mangrove Ecotourism, educators can introduce existing local wisdom and increase the character of caring for the environment for students. As stated by Suratno et al (2015), not only that, local content study materials can provide students with knowledge, skills and behavior so that they have a solid insight into the state of the environment and community needs by the values/rules that apply in their area and support the sustainability of regional development and national development, and Majid (2016) revealed that mangrove ecosystems have various potential benefits, either directly or indirectly. In addition to improving the character of students, local wisdom, mangrove ecotourism can improve students 'understanding, as expressed by Ardan (2016). Local wisdom can improve environmental knowledge and students' attitudes in protecting the environment, Mumpuni (2013); Shufa (2018), argues that learning must contain knowledge, a positive attitude so that it can motivate learning and develop students' skills.

The contribution of this finding show that local wisdom is useful as a means of facing the challenges of the times which can be in the form of filters for foreign cultures that are not following Indonesian local culture, and in the world of education, local wisdom is very useful in improving the quality of the learning process and the output achieved in educational goals. By utilizing one of the local wisdom that exists in a particular area in the world of education, especially in elementary schools, it has a very good impact on the development of the developmental aspects of students, not only in the cognitive aspects but on the affective and psychomotor aspects of students. This research focuses on integrating learning with local wisdom around it, because by including local wisdom it can make it easier for students to understand what is being learned, in accordance with the demands of the latest 2013 curriculum.

\section{CONCLUSION}

Local wisdom of mangrove ecotourism can be integrated into learning at grade IV elementary school, namely on theme 3 sub-themes 1 learning 1 . Integrating local wisdom can provide benefits not only to reintroduce one of the existing wisdom in the province of Jambi but also by utilizing mangrove ecotourism as a field learning place will increase knowledge, skills and create a character that cares for the environment in students who become one of the characters in the current 2013 curriculum guidance 
Local wisdom is useful as a means of facing the challenges of the times which can be in the form of filters for foreign cultures that are not following Indonesian local culture, and in the world of education, local wisdom is very useful in improving the quality of the learning process and the output achieved in educational goals. By utilizing one of the local wisdom that exists in a particular area in the world of education, especially in elementary schools, it has a very good impact on the development of the developmental aspects of students, not only in the cognitive aspects but on the affective and psychomotor aspects of students.

\section{ACKNOWLEDGMENT}

Thank you to all parties involved in the research and manufacture of this article, because without the help of you, the research and production of this article would not be as perfect as it is now

\section{AUTHOR CONTRIBUTION STATEMENT}

This research was conducted by was Syahrial, Asrial, Maison, Dwi Agus Kurniawan, Muhammad Toto Nugroho. They intended to help from the beginning in preparing until the end in reporting of research and supporting of the field more give contribution to collect data.

\section{REFERENCES}

Abadi, M. K., Pujiastuti, H., \& Assaat, L. D. (2017). Development of teaching materials based interactive scientific approach towards the concept of social arithmetic for junior high school student. In Journal of Physics: Conference Series (Vol. 812, No. 1, p. 012015). IOP Publishing.

Albantani, A. M., \& Madkur, A. (2018). Think globally, act locally: the strategy of incorporating local wisdom in foreign language teaching in indonesia. International Journal of Applied Linguistics and English Literature, 7(2), 1-8. https://doi.org/10.7575/aiac.ijalel.v.7n.2p.1

Alsubaie, M. A. (2016). Curriculum Development: Teacher Involvement in Curriculum Development. Journal of Education and Practice, 7(9), 106-107.

Anggari, Angi St,dkk. 2017.Peduli Terhadap Mahkluk Hidup: Buku Tematik Terpadu Kurikulum 2013 untuk SD/MI Kelas IV. Jakarta: Kementrian Pendidikan dan Kebudayaan

Anggraini, P., \& Kusniarti, T. (2015). The insertion of local wisdom into instructional materials of Bahasa Indonesia for 10th grade students in senior high school. Journal of Education and Practice (JEP), 6(3), 89-92.

Anwari, Nahdi, M. S., \& Sulistyowati, E. (2016). Biological science learning model based on Turgo's local wisdom on managing biodiversity. In AIP Conference Proceedings (Vol. 1708, No. 1, p. 030001). AIP Publishing LLC. https://doi.org/10.1063/1.4941146

Ardan, A. S. (2016). The Development of Biology Teaching Material Based on the Local Wisdom of Timorese to Improve Students Knowledge and Attitude of Environment in Caring the Preservation of Environment. International Journal of Higher Education, 5(3), 190-200. https:/ / doi.org/10.5430/ijhe.v5n3p190

Bachri, B. S. (2010). Meyakinkan Validitas Data Melalui Triangulasi Pada Penelitian Kualitatif. Teknologi Pendidikan, 10, 46-62.

Creswell, John W. (2014). Research Design, Qualitatives, Quantitative, and Mixed Methods Approcahes (Fourth Edition). United State of America: Sage Publications. 
Darmadi, H. (2018). Educational Management Based on Local Wisdom (Descriptive Analytical Studies of Culture of Local Wisdom in West Kalimantan). Journal of Education, Teaching and Learning, 3(1), 135-145. http://dx.doi.org/10.26737/jetl.v3i1.603

Guvercin, S., \& Verbovskiy, V. (2014). The effect of problem proposing tasks used in mathematics instruction to mathematics academic achievement and attitudes toward mathematics. International Online Journal of Primary Education, 3(2), 5965.

Hairida, H. (2017). Using Learning Science, Environment, Technology and Society (SETS) Local Wisdom and based Colloids Teaching Material. Journal of Education, Teaching and Learning, 2(1), 84-89. http://dx.doi.org/10.26737/jetl.v2i1.146

Kahar, A. P. (2018). Penerapan bahan ajar ekosistem mangrove berbasis potensi lokal untuk meningkatkan sikap peduli lingkungan siswa. Didaktika Biologi: Jurnal Penelitian Pendidikan Biologi, 2(1), 1-8. https:// doi.org/10.32502/dikbio.v2i1.886

Kemendikbud. (2013). Peraturan Menteri Pendidikan Nomor 81A Tahun 2013 tentang Implementasi Kurikulum

Khusniati, M., Parmin, P., \& Sudarmin, S. (2017). Local wisdom-based science learning model through reconstruction of indigenous science to improve student's conservationist character. Journal of Turkish Science Education, 14(3), 16-23. https:// doi.org/10.12973/tused.10202a

Kusuma, R. S. (2018). Peran sentral kearifan lokal dalam peningkatan kualitas pendidikan. pedagogik: jurnal pendidikan, 5(2), 228-239. https://doi.org/10.33650/pjp.v5i2.385

Machali, I. (2014). Kebijakan perubahan kurikulum 2013 dalam menyongsong Indonesia emas tahun 2045. Jurnal Pendidikan Islam,3(1), 71-94. https://doi.org/10.14421/jpi.2014.31.71-94

Majid, I., Al Muhdar, M. H. I., Rohman, F., \& Syamsuri, I. (2016). Konservasi Hutan Mangrove Di Pesisir Pantai Kota Ternate Terintegrasi dengan Kurikulum Sekolah. BIOEDUKASI, 4(2).

Manan, M. (2015). The Implementation of the Right to Education in Indonesia. Indonesia Law Review, 5(1), 51. https:/ / doi.org/10.15742/ilrev.v5n1.137

Miles, M. B., \& Huberman, A. M. (1994). Qualitative data analysis (2nd ed.). Thousand Oaks, CA: Sage.

Mumpuni, K. E. (2013, October). Potensi pendidikan keunggulan lokal berbasis karakter dalam pembelajaran biologi di indonesia. In Prosiding Seminar Biologi (Vol. 10, No. 2).

Ningrum, E., \& Sungkawa, D. (2018). The impact of local wisdom-based learning model on students' understanding on The land ethic. In IOP Conference Series: Earth and Environmental Science (Vol. 145, No. 1, p. 012086). IOP Publishing. https:/ / doi.org/10.1088/1755-1315/145/1/012086

Pemerintah Republik Indonesia. (2003). Undang-Undang Republik Indonesia Nomor 20 Tahun 2003 tentang Sistem Pendidikan Nasional. Jakarta.

Pemerintah Republik Indonesia. (2013). Peraturan Pemerintah Republik Indonesia Nomor 81A Tahun 2013 Tentang Implementasi Kurikulum. Jakarta.

Putri, A. S., \& Aznam, N. (2019). The Effect of the Science Web Module Integrated on Batik's Local Potential towards Students' Critical Thinking and Problem Solving (Thinking Skill). Journal of Science Learning, 2(3), 92-96. https://doi.org/10.17509/jsl.v2i3.1684 
Ratnasari, D., Koosbandlah, R. H., \& Supriatno, B. (2017). Penggunaan Metode Field Trip Mangrove Cagar Alam Pulau Dua Terhadap Penguasaan Konsep Siswa. Jurnal Pendidikan http:/ / dx.doi.org/10.23960/jpp.v7.i2.201711

Progresif, 7(2),

88-92.

Rijali, A. (2019). Analisis data kualitatif. Alhadharah: Jurnal Ilmu Dakwah, 17(33), 81-95.

Saglam, H. I. (2011). An Investigation on Teaching Materials Used in Social Studies Lesson. Turkish Online Journal of Educational Technology-TOJET, 10(1), 36-44.

Santosa, A. B., Basuki, Y., \& Puspita, A. M. I. (2019). The Effectiveness of Local Wisdom-Based Teaching Materials in Enhancing Creative Writing Skills of Elementary School Students. Journal of English Language Teaching and Linguistics, 4(3), 349-359. http:// dx.doi.org/10.21462/jeltl.v4i3.326

Saputri, D. N., Winarni, E. W., \& Gunawan, A. (2019). Pengaruh Pemanfaatan Hutan Mangrove sebagai Sumber Belajar IPA terhadap Sikap Peduli Lingkungan Siswa Kelas IV SD Kota Bengkulu. Jurnal PGSD: Jurnal Ilmiah Pendidikan Guru Sekolah Dasar, 12(2), 150-158. https:// doi.org/10.33369/pgsd.12.2.150-158

Shaleha, M. A., \& Purbani, W. (2019). Using Indonesian local wisdom as language teaching material to build students' character in globalization era. KnE Social Sciences, 292-298. https:// doi.org/10.18502/kss.v3i10.3910

Shufa, N. K. F. (2018). Pembelajaran Berbasis Kearifan Lokal Di Sekolah Dasar: Sebuah Kerangka Konseptual. INOPENDAS: Jurnal Ilmiah Kependidikan, 1(1). https://doi.org/10.24176/jino.v1i1.2316

Sibarani, R. (2018). The role of local wisdom in developing friendly city. In IOP Conference Series: Earth and Environmental Science (Vol. 126, No. 1, p. 012094). IOP Publishing. https:// doi.org/10.1088/1755-1315/126/1/012094

$\mathrm{Su}, \mathrm{S}$. W. (2012). The Various Concepts of Curriculum and the Factors Involved in Curricula-making. Journal of language teaching $\mathcal{E}$ research, 3(1). https://doi.org/10.4304/jltr.3.1.153-158

Suastra, I. W., Jatmiko, B., Ristiati, N. P., \& Yasmini, L. P. B. (2017). Developing characters based on local wisdom of Bali in teaching physics in senior high school. Jurnal Pendidikan IPA Indonesia, 6(2), 306312. https://doi.org/10.15294/jpii.v6i2.10681

Subali, B., Sopyan, A., \& Ellianawati, E. (2015). Developing local wisdom based science learning design to establish positive character in elementary school. Jurnal Pendidikan Fisika Indonesia, 11(1), 1-7. https:/ / doi.org/10.15294/jpfi.v11i1.3998

Sugiyono. (2017). Metode Penelitian Kuantitatif, Kualitatif, dan RED. Bandung : Alfabeta, $\mathrm{CV}$

Sulistyowati, E., Rohman, F., \& Ibrohim, I. (2020). Perangkat Pembelajaran Inkuiri Terbimbing Berbantuan Handout Berbasis Potensi Lokal Hutan Mangrove untuk Meningkatkan Kemampuan Berpikir Kritis dan Sikap Peduli Lingkungan. Jurnal Pendidikan: Teori, Penelitian, dan Pengembangan, 5(3), 374-379. http://dx.doi.org/10.17977/jptpp.v5i3.13272

Suratno, S., Swandari, F., \& Yamin, M. (2015). Pengembangan Model Pembelajaran Berbasis Kearifan Lokal di Daerah Bantaran Sungai Barito. Jurnal Pendidikan Progresif, 5(2), 178-189.

Syaputra, E. (2019). Pandangan Guru Terhadap Integrasi Kearifan Lokal Dalam Pembelajaran Sejarah: Studi Deskriptif Di Beberapa Sma Di Bengkulu Selatan Dan Kaur. Indonesian Journal of Social Science Education (IJSSE), 1(1), 1-10. http://dx.doi.org/10.29300/ijsse.v1i1.1321 
Tanjung, P., Daulay, S., \& Ghafari, O. F. (2018). The development of lokal wisdom of Labuhanbatu based on teaching material of descriptive text for 7th grade student at SMP Negeri 1 Bilah Barat, Indonesia. International Journal of Education, Learning and Development, 6(1), 80-92.

Uge, S., Neolaka, A., \& Yasin, M. (2019). Development of Social Studies Learning Model Based on Local Wisdom in Improving Students' Knowledge and Social Attitude. International Journal of Instruction, 12(3), 375-388. . https://doi.org/10.29333/iji.2019.12323a

Utari, U., \& Degeng, I. N. S. (2017). Pembelajaran tematik berbasis kearifan lokal di sekolah dasar dalam menghadapi Masyarakat Ekonomi Asean (MEA). Jurnal Teori dan Praksis Pembelajaran IPS, 1(1), 39-44. http:/ /dx.doi.org/10.17977/um022v1i12016p039

Vallori, A. B. (2014). Meaningful learning in practice. Journal of Education and Human development, 3(4), 199-209. http://dx.doi.org/10.15640/jehd.v3n4a18

Wagiran, W. (2012). Pengembangan Karakter Berbasis Kearifan Lokal Hamemayu Hayuning Bawana (Identifikasi Nilai-Nilai Karakter Berbasis Budaya). Jurnal Pendidikan Karakter, (3).

Winataputra, U. S., \& Al Rakhman, R. (2013, January). Curriculum Improvement for Better Indonesian Education: A Reconstructed Philosophy of Education Revisited. In International Conference on Education and Language (ICEL) (Vol. 1).

Yamin, M. (2017). Integrating the local wisdom values into the national curriculum to create the nationalism strength. Journal of Education and Practice, 8(3).

\section{Copyright Holder :}

(C) Syahrial, S., et al., (2021).

First Publication Right :

(c) Jurnal Iqra' : Kajian Ilmu Pendidikan

This article is under:

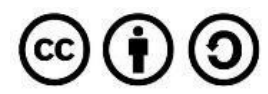

